\title{
SEMIOTIKA
}

Volume 19

Nomor 2, Juli 2018

Halaman $67-75$

URL: https://jurnal.unej.ac.id/index.php/SEMIOTIKA/index

E-ISSN: 2599-3429

P-ISSN: $1411-5948$

\section{MODEL AKTAN GREIMAS DALAM NOVEL MENCARI PEREMPUAN YANG HILANG KARYA IMAD ZAKI}

\author{
GREIMAS' ACTANTIAL MODEL IN IMAD ZAKI'S MENCARI PEREMPUAN YANG HILANG
}

\author{
Erna Megawati \\ Universitas Indraprasta PGRI Jakarta Selatan \\ Corresponding Author: 45megawatie@gmail.com \\ Informasi Artikel:
}

Dikirim: 10/3/2018; Direvisi: 7/4/2018; Diterima: 14/5/2018

\begin{abstract}
The aim of this research is to discover the structure of fabula within the novel of Mencari Perempuan Yang Hilang. The method used in the research was narratology. Data is collected using library. Research is analyzed based on the theory of actantial model by Greimas. The result shows if the novel has six actants as suggested by Greimas which are subject, object, sender, receiver, helper, and opponent.
\end{abstract}

Keywords: actant, narratology, structure

\begin{abstract}
Abstrak
Tujuan dari penelitian ini adalah untuk menemukan struktur fabula dalam novel Mencari Perempuan yang Hilang. Metode yang digunakan dalam penelitian ini adalah narratologi. Data dikumpulkan menggunakan studi pustaka. Penelitian dianalisis berdasarkan teori model actantial oleh Greimas. Hasil penelitian menunjukkan bahwa novel ini memiliki enam aktor seperti yang disarankan oleh Greimas, yaitu subjek, objek, pengirim, penerima, pembantu, dan lawan.
\end{abstract}

Kata kunci: aktan, naratologi, struktur

\section{PENDAHULUAN}

Asumsi bahwa novel merupakan replika kenyataan telah menjadikan novel sebagai media pembelajaran yang efektif karena menampilkan properti yang tidak asing. Sebuah novel dapat dikaji dari berbagai sudut pandang guna diambil kebermanfaatannya. Pada bidang pendidikan, Dewi, Putrayasa, dan Nurjaya (2014) menemukan bahwa dalam novel terdapat nilai-nilai karakter seperti religius, toleransi, disiplin, dan kerja keras. Penelitian tersebut juga menunjukkan adanya relevansi antara nilai-nilai dengan pengajaran pendidikan. Temuan ini menjadi bukti bahwa novel mampu menyediakan bahan ajar karakter bagi peserta didik. Novel juga dapat dijadikan media pembelajaran 
multikultural,seperti yang dilakukan oleh Al-Ma'ruf (2007). Pendidikan multikultural sangat diperlukan seiring dengan globalisasi. Paradigma multikultural tersebut dapat dikenalkan dengan menjadikan novel sebagai media pembelajarannya. Hal ini sejalan dengan dinamika dan dialektika perkembangan zaman.

Untuk menjadikan novel sebagai sebuah media dalam pendidikan dan pembelajaran, seseorang harus memilih novel secara seksama. Tidak semua novel otomatis dapat dijadikan media pembelajaran yang aman karena tidak sedikit novel yang mempunyai konten tidak layak. Salah satu novel yang aman dijadikan media dalam pembelajaran biasanya berupa novel profetik karena ceritanya berisi kebaikan versus kejahatan. Novel Mencari Perempuan yang Hilang merupakan salah satu novel yang menyajikan pergulatan nilai kebaikan dan kejahatan. Hal ini mendorong penulis untuk meneliti novel tersebut dengan pendekatan naratologi dengan menggunakan teori aktan dari Algirdas Julien Greimas (1987).

State of the art dalam sebuah penelitian adalah unsur kebaruan dari penelitian yang dilakukan oleh peneliti dibandingkan dengan hasil penelitian sebelumnya. Kebaruan dapat berupa topik, penemuan, inovasi, model, objek, kasus, subjek, metode, dan hal lainnya. Kebaruan dari penelitian ini berupa subfokus penelitian yang berupa model aktan Greimas (1987).

Berdasarkan latar belakang di atas, pertanyaan pada penelitian ini adalah bagaimana struktur naratif dalam novel Mencari Perempuan yang Hilang karya Imad Zaki yang dialihbahasakan oleh Zuriyati berdasarkan teori aktan Greimas? Penelitian terdahulu yang terkait dengan struktur naratif Greimas di antaranya penelitian Resita dan Oemita, dan penelitian Agati. Penelitian Resita dan Oemita (2009) yang berjudul "Analisis Struktural dalam Cerpen 'Hana' Karya Akutagawa Ryounosuke" menganalisis penerapan model aktan Greimas dan model Fungsional. Temuan penelitian ini menunjukkan bahwa cerita tersebut memiliki dua belas skema aktan, yang mempunyai fungsi utuh atau sempurna. Sementara itu, penelitian Agati (2009) yang berjudul "Struktur Naratif dalam Yodaka No Hoshi Karya Miyazawa Kenji Menurut Teori Naratologi Greimas" menganalisis untuk menemukan struktur teks melalui tujuh fungsi aktan yaitu subjek, objek, receiver, helper dan opponent. Penelitian ini juga menerapkan model fungsional melalui beberapa fase, yaitu: situasi awal, tahap transformasi, dan situasi akhir.

Konsep-konsep terkait fokus dan subfokus yang dijadikan landasan bagi penulis dalam penelitian ini yaitu konsep model aktan Greimas dalam novel. Teori Greimas (1987) tentang Narrative Program/Quest struktur naratif ditelusuri dalam tingkat sintagmatik, sementara teori model aktan akan menelusuri naratif dalam tingkat paradigmatik. Analisis aktan digunakan sebagai alat untuk menganalisis teks sastra atau citraan yang bertujuan untuk menemukan struktur teks.

Asumsi dasar model aktan merupakan satu pandangan bahwa tindakan manusia mengarah kepada satu tujuan tertentu (teleologis). Asumsi ini kemudian digunakan untuk menghubungkan antartokoh cerita dan tindakannya yang membentuk suatu aktan tertentu. Bal (1997:6) mendefinisikan, 'An actant'is a class of actors that shares a certain 
characteristic quality. That shared characteristic is related to the teleology of the fabula as a whole ...' aktan merupakan sekelompok pelaku yang mempunyai karakteristik tertentu. Karakter tersebut terkait dengan teleologis riwayat secara keseluruhan. Hubungan dari kelompok aktor tersebut membentuk fungsi. X dihubungkan kepada $\mathrm{Y}$ oleh sebuah fungsi. Sebagai contoh, $\mathrm{X}$ ingin mencintai $\mathrm{Y}$, maka 'ingin mencintai' merupakan fungsi yang menghubungkan aktan $\mathrm{X}$ dan $\mathrm{Y}$

Model aktan menyederhanakan teori Propp dan Souriau ke dalam oposisi paradigmatik yang disebut 'actants,' sebuah istilah yang mengacu ke fungsi dan peran dari tiap elemen di dalam naratif. Greimas (1987:25) menyebutkan versi aktan menjadi: subjek (elemen yang mencari) dan objek (elemen yang dicari oleh subjek): pengirim (elemen yang mengirim objek) dan penerima: tujuan (tidak khusus tempat), serta pengirim dan penerima.

Aktan subjek dan objek merupakan aktan utama dalam cerita. Hubungan ini merupakan hubungan antara seseorang yang mengejar tujuan dan tujuan itu sendiri. Aktor $\mathrm{X}$ berkeinginan mencapai $\mathrm{Y}$ sehingga $\mathrm{X}$ merupakan aktan subjek, sedangkan $\mathrm{Y}$ adalah aktan objek. Sebagai contoh, Jhon ingin menikahi Marry. Jhon merupakan subjek, dan Mary adalah objek. Elemen yang menunjukkan maksud riwayat (cerita) ditunjukkan dalam bentuk 'ingin menikahi', sedangkan objek tidak selalu dalam wujud sosok orang karena subjek dapat saja bercita-cita untuk mencapai satu tujuan tertentu. Sebagai contoh, subjek dapat bercita-cita menjadi seseorang yang berkuasa, memiliki kekayaan, kebijakan, atau kebahagiaan.

Maksud dari subjek tidak cukup untuk mencapai objek. Untuk itu selalu ada kekuasaan yang memungkinkan untuk mencapai tujuan tersebut. Kekuasaan (pengirim) ini dalam banyak hal bukan sosok orang melainkan sebuah abstraksi, seperti: masyarakat, takdir, waktu, dan kecerdasan. Di sisi lain, penerima merupakan sesorang yang menerima kekuasaan tersebut. Penerima dapat berada di dalam sosok orang. Dalam sebuah dongeng, pengirim biasa muncul dalam cerita sebagai sosok raja yang mempunyai kuasa untuk menikahkan putrinya dengan subjek yang diinginkan. Penerima seringkali berupa orang yang sama dengan subjek. Dia menginginkan sesuatu/seseorang untuk dirinya sendiri. Secara prinsip, subjek dan kekuasaan lebih mendominasi dan lebih aktif jika ditinjau secara gramatika dibandingkan objek dan penerima. Sebagai contoh, 'struktur sosial yang berlaku menjadikan hal tersebut mustahil baginya.' Struktur sosial berlaku sebagai pengirim, sedangkan 'baginya' menjadi penerima.

Aktan penolong dan penentang terkait erat dengan aktan subjek. Hal ini karena dalam usaha subjek mencapai tujuan, subjek terkadang menemui hambatan dari penentang atau menerima bantuan dari penolong. Aktan ini tidak terhubung langsung dengan objek tetapi terhubung dengan fungsi yang menghubungkan subjek dengan objek. Jika tokoh mempermudah subjek dalam mencapai tujuannya, tokoh tersebut adalah penolong. Sebaliknya, jika tokoh atau sesuatu menghalangi subjek dalam memcapai tujuannya, aktan tersebut merupakan aktan penentang. Sebagai contoh, ketiadaan bukti menghalangi Rondang untuk membunuh pemerkosa (ketiadaan bukti merupakan penentang); Pak Tatung membantu Rondang untuk menghapus rasa bersalah (Pak Tatung merupakan penolong) 
Model aktan Greimas (1987) lebih lanjut dikembangkan ke dalam tiga sumbu berbeda: sumbu dari keinginan/proyek membicarakan dua aktan (subjek dan objek), dan satu 'junction' (hubungan antara). 'Conjunction' merupakan hubungan positif (subjek menginginkan untuk bersama objek) dan hubungan negatif (subjek ingin berpisah dari objek sabagai 'disjunction'). Disjunction merupakan sumbu dari power/konflik yang bicara mengenai hubungan antara helper dan opponent. Peran helper untuk menjamin hubungan yang diinginkan antara subjek dan objek. Sumbu dari transmisi/pengetahuan/komunikasi membangun hubungan antara sender (elemen yang menanyakan hubungan subjek dan objek) dan receiver (elemen yang dapat meningkatkan keuntungan dari pembangunan hubungan tersebut).

Menurut Ratna (Resita \& Oemiati, 2009), teori Greimas diklasifikasikan ke dalam strukturalisme naratologi karena mempunyai kelebihan berupa konsep penyajian yang terperinci dan di dalam penyajian tersebut terdapat alur cerita kehidupan tokoh-tokoh yang dapat menjembatani pemahaman cerita tersebut melalui teks yang menjadi media komunikasi antara pengarang dan pembaca.

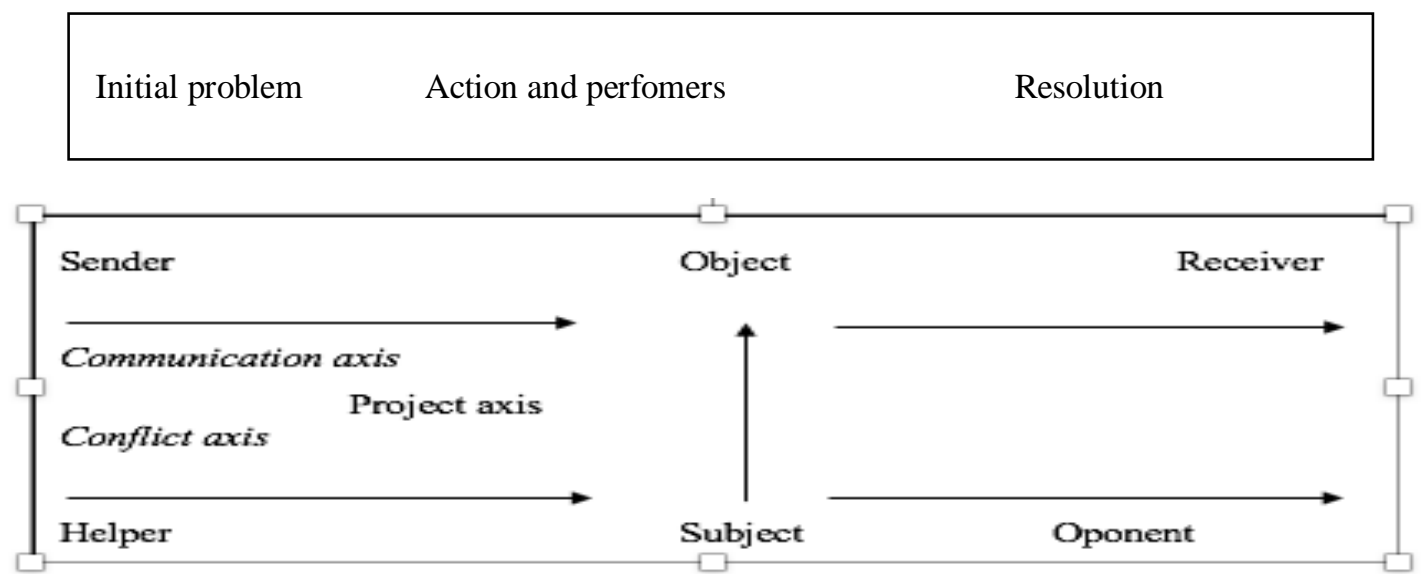

Eagleton (2005:11) menjelaskan bahwa ada banyak cara untuk mendefinisikan karya sastra. Definisi yang paling ringkas adalah 'imaginative' writing in the sense of fiction - writing which is not literally true." Sastra adalah tulisan fiksi - imajinatif yang tidak nyata benar. Namun, sulit untuk memisahkan secara nyata antara fakta dan fiksi. Pada akhir abad 16 awal abad 17, kata 'novel' digunakan untuk kondisi benar atau fiksi.

Sastra bagi kaum formalis dinyatakan Eagleton (2005:13), "The Formalists, then, saw literary language as a set of deviations from a norm, a kind of linguistic violence: literature is a 'special' kind of language, in contrast to the 'ordinary' language we commonly use. But to spot a deviation implies being able to identify the norm from which it swerves...". Jadi, bagi para Formalis, bahasa sastra sebagai seperangkat deviasi norma, pelanggaran terhadap linguistik. Namun, pada faktanya karena bahasa terdiri atas susunan kompleks berdasarkan kelas, wilayah, gender, dan status, tidak mungkin untuk 
menggabungkan semua bahasa menjadi satu komunitas linguistik yang homogen. Dengan demikian, norma bahasa pada satu orang bisa menjadi pelanggaran bagi yang lainnya.

Dalam pandangan golongan New Critics, karya sastra bersifat Autotelic (Holman \& Kenan, 1992:20). Artinya, istilah yang digunakan untuk mengistilah sebuah karya yang nondidaktik yakni suatu karya yang tujuan akhir dan maksudnya berada pada karya itu sendiri dan tidak bergantung pada pencapain tujuan di luar karya tersebut. Oleh Kritikus Baru, istilah ini ditujukan pada sebuah puisi, khususnya puisi yang bicara kebenarannya sendiri dan tidak mengacu pada nilai kebenaran eksternal. Sebaliknya, karya yang didaktik bertujuan untuk memberikan panduan mengenai moral, etik, dan masalah keagamaan karena semua karya sastra dianggap bertujuan mengkomunikasikan sesuatu seperti yang diajukan oleh Marxis.

Pembagian sastra secara umum adalah puisi, fiksi, dan drama. Pembagian ini merupakan pembagian pokok. Prosa fiksi terbagi menjadi cerpen, novel, dan roman. Novel merupakan suatu cerita yang fiktif, melukiskan para tokoh, gerak, dan adegan kehidupan nyata yang representatif dalam suatu alur atau suatu keadaan tertentu.

Novel Mencari Perempuan yang Hilang bercerita mengenai kisah cinta, kehidupan anak manusia, berisi moral hingga menghadirkan kekejaman seorang ayah. Penulis menyajikan kisah percintaan antartokoh yaitu Sholeh dan tokoh wanita bernama Ahlam, Sholeh merupakan seorang dokter spesialis yang lulus dengan predikat terpuji (cumlaude). Sholeh bekerja di rumah sakit Ibnu Nafis, tempat berkumpulnya dokter spesialis.

Sholeh lahir dari keluarga yang sederhana, berkecukupan harta dan kasih sayang. Ayah Sholeh merupakan sosok laki-laki gigih yang bekerja dengan giat tanpa berkeluh kesah untuk menghidupi keenam anaknya termasuk Sholeh, sedangkan sang ibu adalah seorang ibu rumah tangga yang mendidik keenam anaknya dengan penuh kasih sayang dan kelembutan.

Sebaliknya, Ahlam adalah seorang gadis cantik yang juga bekerja di rumah sakit Ibnu Nafis bersama Sholeh. Ayah Ahlam adalah seorang kaya raya yang memiliki gedunggedung megah, salah satunya adalah pusat perbelanjaan terbesar bernama al-Burju Azraq (menara biru). Ibu Ahlam adalah seorang perempuan konglomerat yang aktif di kegiatan organisasi perkumpulan para wanita kaya.

Ahlam dibesarkan dengan harta yang berlimpah. Ia dibesarkan dengan tiga orang pembantu yang mengurusi seluruh keperluan. Masing-masing asisten rumah tangga memiliki tanggug jawab berbeda yaitu kebersihan, keperluan makan, dan menjaga kesehatan Ahlam. Ahlam dibesarkan bagaikan seorang puteri raja yang bergelimang kemewahan.

Novel Mencari Perempuan yang Hilang adalah kisah pilu seorang wanita yang menghilang dari peradaban karena berat untuk menanggung beban kejahatan ayahnya yang merugikan orang banyak. Kisah seorang wanita yang menghilang dari peradaban karena tidak menikahi kekasih pujaannya karena sikap ayahnya yang arogan, ambisius, dan serakah, serta kisah seorang anak yang tidak dididik dengan benar dan penuh kasih sayang oleh orang tuanya. 
Penelitian ini relevan dilakukan terkait kajian naratologi model aktan Greimas untuk menganalisis novel Mencari Perempuan yang Hilang. Sebagaimana yang dilakukan oleh Kilmukhametova dan Marugina (2014) dalam "Narratology as a Platform for the Study of Non-Verbal Means of Communication (Using Fiction as an Example)," penelitian ini menganalisis struktur dan bagian dari komunikasi naratif yang dipandang dari posisi naratologi. Penelitian ini membuktikan naratologi dapat menjadi dasar untuk kajian deskripsi verbal untuk alat komunikasi nonverbal. Kajian alat nonverbal dari posisi teori naratif menunjukkan bagian sebenarnya sebuah karakter dalam penciptaan citraannya. Hal tersebut memungkinkan pembaca menentukan maksud dari penulis.

\section{METODE}

Penelitian ini merupakan penelitian naratologi. Naratologi, menurut beberapa ahli dalam buku Ratna (2013:128 - 132) berasal dari kata naratio (bahasa Latin, yang berarti cerita; perkataan; kisah atau hikayat) dan logos yang berarti ilmu. Naratologi dikenal juga sebagai teori wacana naratif. Dalam pendekatan naratologi, teks dipandang sebagai sebuah teks naratif yang mengandung fitur khusus komunikasi (Schmid, 2010). Naratologi atau teori wacana (teks) naratif merupakan seperangkat konsep mengenai cerita dan pen(cerita)an. Dasar perkembangan naratologi adalah analogi linguistik, seperti model sintaksis, seperti halnya hubungan antara subjek, predikat, dan objek penderita. Objek penelitian Greimas tidak hanya pada satu genre tertentu seperti dongeng, tetapi meluas kepada mitos (Ratna, 2013:137). Analisis mengenai aktan dan fungsinya dalam cerita, akan menggunakan model aktan dari Algirdas Julien Greimas.

Analisis aktan dan fungsi merupakan analisis alur cerita yang didasari hubungan antaraktan. Aktan (actant) merupakan peran-peran abstrak yang dapat dimainkan oleh seseorang atau sejumlah pelaku. Greimas lebih mementingkan aksi dibandingkan dengan pelaku. Hal tersebut dapat dicermati pada diagram berikut.

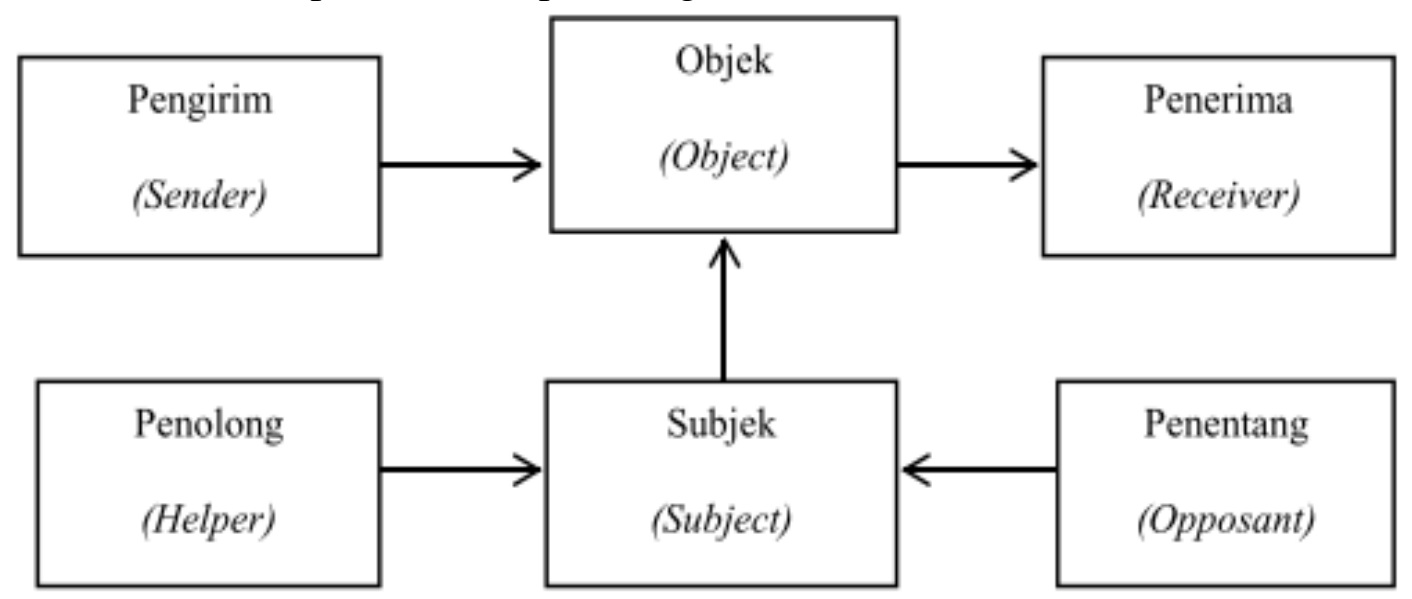

Sumber data dari penelitian ini yaitu novel Mencari Perempuan yang Hilang karya Imad Zaki dan dialihbahasakan oleh Zuriyati. Fokus dari penelitian ini adalah adegan 
dalam novel Mencari Perempuan yang Hilang. Subfokus penelitian ini adalah aktan Greimas dalam novel tersebut.

Instrumen penelitian ini adalah peneliti sendiri (human instrument). Teknik pengumpulan data pada penelitian ini adalah teknik pustaka dan kajian dokumen. Dalam proses pengumpulan data, peneliti melakukan tiga kegiatan. Pertama, peneliti membaca novel sumber yaitu novel Mencari Perempuan yang Hilang karya Imad Zaki dan dialihbahasakan oleh Zuriyati. Setelah membaca novel itu, peneliti melihat adegan yang ada dalam novel tersebut. Ketiga, setelah terkumpul data, peneliti siap untuk menganalisisnya.

\section{HASIL DAN PEMBAHASAN}

Hasil dan pembahasan terhadap novel Mencari Perempuan yang Hilang dengan menggunakan teori naratologi Greimas ini dituangkan dalam beberapa bagian, yakni profil unit analisis, penyajian hasil, dan uraian pembahasan. Hal tersebut dipaparkan dalam analisis berikut.

\section{Profil Unit Analisis}

Novel Mencari Perempuan yang Hilang merupakan novel karangan Imad Zai yang dialihbahasakan oleh Zuriyati. Novel ini diterbitkan oleh Markaz ar-Rayah dengan editor Abu Fawwaz. Novel Mencari Perempuan yang Hilang terdiri atas 368 halaman. Novel ini menyajikan pergulatan nilai kebaikan dan kejahatan. Novel ini berisi kisah seorang wanita yang menghilang dari peradaban sebagai akibat beratnya menanggung beban kejahatan ayahnya yang merugikan banyak orang.

\section{Hasil Penelitian}

Hasil penelitian terhadap novel Mencari Perempuan yang Hilang dengan menggunakan konsep naratologi Greimas menunjukkan rangkaian narasi yang memenuhi peran masing-masing antara pengirim, objek, penerima, penolong, subjek, dan penentang. Hal ini sejalan dengan konsep model aktan yang dipopulerkan oleh Greimas. Hasil penelitian dapat diketahui bahwa pengirim dalam konteks novel ini adalah rasa cinta yang tulus. Hal tersebut menjadi pemicu utama bergulirnya rangkaian alur dalam kisah asmara ini. Selanjutnya, objek yang menjadi acuan adalah tokoh yang bernama dr. Ahlam, sedangkan pihak yang menjadi penerima dr. Sholeh. Dalam konteks penerima ini, dr. Sholeh ingin menikahi dr. Ahlam. Sementara itu, yang menjadi penolong adalah Paman Darwis, sedangkan yang menjadi subjek adalah dr. Sholeh. Penentang dari rangkaian alur kisah asmara tersebut adalah Abdul Ghani Zahabi. Rangkaian alur kisah asmara tersebut dapat dituangkan dalam bentuk diagram berikut. 


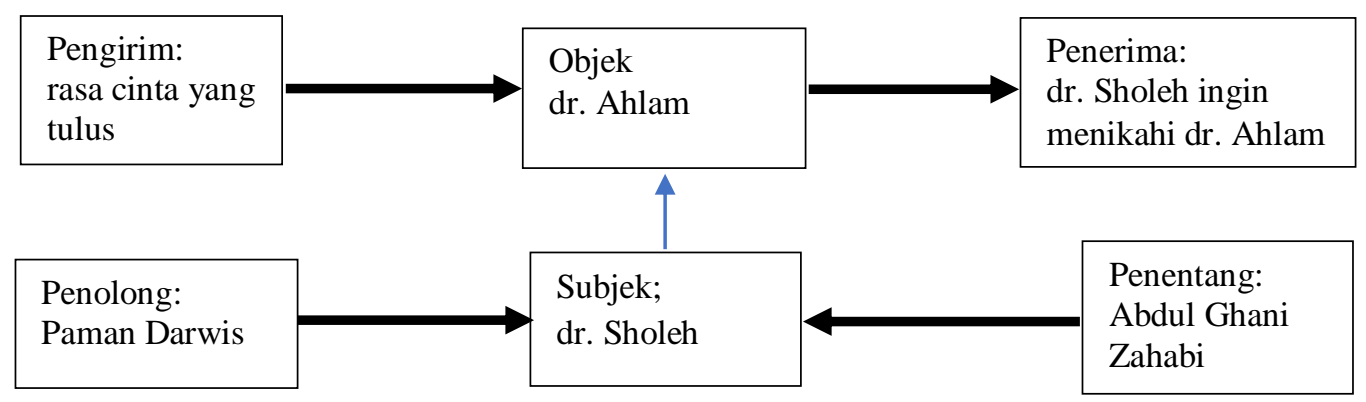

\section{Pembahasan terhadap Hasil Penelitian}

Secara keseluruhan cerita (fabula) dari novel Mencari Perempuan yang Hilang mempunyai struktur berdasarkan model Aktan Greimas sebagai berikut.

a) Subjek dan Objek

Aktan dominan yaitu subjek dan objek dari novel Mencari Perempuan yang Hilang adalah dr. Sholeh sebagai subjek yaitu pelaku yang menginginkan sesuatu. Antara subjek dan objek dihubungkan oleh fungsi 'ingin menikahi' dr. Ahlam yang berkedudukan sebagai aktan objek.

b) Pengirim dan Penerima

Dalam usaha subjek mencapai tujuannya, aktan yang berkuasa (pengirim) adalah rasa cinta yang tulus yang dimiliki oleh subjek terhadap objek. Rasa cinta inilah yang mendorong subjek untuk berusaha mencapai tujuannya yaitu menikahi dr. Ahlam. Aktan penerima dalam cerita ini adalah subjek ingin menikahi objek.

c) Penolong dan Penentang

Dalam usahanya mencapai tujuan, subjek dibantu oleh pelaku penolong, dalam hal ini Paman Darwis yang senantiasa memberikan dukungan bagi subjek. Paman Darwis selalu datang memberikan nasihat yang menenangkan subjek ketika subjek dilanda banyak persoalan. Sosok penolong yang kebapakan telah membuat subjek merasa nyaman ketika mendengarkan nasihat penolong. Sebaliknya, pelaku penentang dari novel ini adalah Abdul Ghani Zahabi. Abdul Ghani Zahabi adalah ayah dari dr. Ahlam yang dicintai subjek. Tokoh Abdul Ghani Zahabi adalah tokoh yang arogan, ambisius, menghalalkan segala cara untuk mencapai keinginannya. Dia menentang lamaran subjek dan menyusun rencana jahat untuk menjauhkan dr. Ahlam dari dr. Sholeh.

\section{SIMPULAN}

Berdasarkan penelitian naratologi ini, sebuah cerita menjadi nyata secara fabula dan sjuzet. Analisis model aktan Greimas menunjukkan bahwa dalam sebuah cerita terdapat enam aktan sebagai struktur cerita. Melalui analisis aktan, memudahkan pembaca dalam memaknai sebuah cerita dan penceritaan. Analisis ini juga memungkinkan pembaca untuk mengambil implikasi cerita ke dalam kehidupan melalui fungsi-fungsi aktan dalam model Greimas. 


\section{DAFTAR PUSTAKA}

Agati, N. 2009. "Struktur Naratif dalam Yodaka No Hoshi Karya Miyazawa Kenji Menurut Teori Naratologi Greimas." Dalam https://core.ac.uk/download/pdf/35373978.pdf (diakses 12 Januari 2018).

Al-Ma'ruf, A. I. 2007. "Pembelajaran Sastra Multikultural di Sekolah: Aplikasi Novel Burung-Burung Rantau. Kajian Linguistik dan Sastra, 19 (1):60--75.

Bal, M. 1997. Narratology: Introduction to the Theory of Narrative. University of Toronto Press. https://doi.org/10.2307/3685217 (diakses 15 Januari 2018).

Dewi, N. L. L. A., Putrayasa, I. B., \& Nurjaya, I. G. 2014. "Analisis Nilai-nilai Pendidikan Karakter Novel Sepatu Dahlan Karya Khrisna Pabichara dan Relevansinya terhadap Pengajaran Pendidikan Karakter Sekolah di Indonesia." Jurnal Pendidikan Bahasa dan Sastra Indonesia, Undiksha, 2(1). Dalam http://ejournal.undiksha.ac.id/index.php/JJPBS/article/viewFile/3438/2799. (diakses 15 Januari 2018).

Eagleton, T. 2005. Literary Theory. Blackwell Publishing.

Greimas, A. J. 1987. On Meaning: Selected Writings in Semiotic Theory (Theory and History of Literature). University of Minnesota Pr.

Holman, C. H., \& Kenan. 1992. A Handbook to Literature. ITT Bobbs-Merrill Educational Publishi.g Company, Inc.

Kilmukhametova, E. Y., \& Marugina, N. I. 2014. "Narratology as a Platform for the Study of Non-Verbal Means of Communication (Using Fiction as an Example). Procedia Social and Behavioral Sciences, 154 (October), 407--411. https://doi.org/10.1016/j.sbspro.2014.10.176 (diakses 15 Januari 2018).

Ratna, N.K. 2013. Teori, Metode, dan Teknik Penelitian Sastra. Yogyakarta: Pustaka Pelajar.

Resita, E., \& Oemiati, S. 2009. "Analisis Struktural dalam Cerpen 'Hana' Karya Akutagawa Ryounosuke. Jurnal pada Program Studi Bahasa Jepang, Fakultas Bahasa, Universitas Dian Nuswantoro. Dalam http://eprints.dinus.ac.id/8321/1/jurnal_14080.pdf (diakses 15 Januari 2018).

Schmid, W. 2010. Narratology: An Introduction. Walter de Gruyter GmbH \& Co. KG, Berlin/New York. 